衣料文化生産主導から機関投資家主導の都市細街路成長へ 東京都渋谷区神宮前の文化生産街区における投資に着目した研究

\title{
Changes in the Close Alleys of the Jingu-Mae Shibuya Ward in Tokyo:
}

From the standpoint of Cultural Production and Investment

\section{三田知実 \\ Tomomi MITA}

This paper explores changes in urban spaces among the close alleys of the JinguMae Shibuya Ward in Tokyo from the standpoint of cultural production and the emergence of investment companies. This paper will also discuss this case study from an urban sociology standpoint.

The close alleys in the Jingu-Mae area of Shibuya Ward in Tokyo were residential streets until the 1980s. However, from the 1990s, these close alleys changed from residential streets to a global hub for upscale clothing design. With this change, the close alleys of Jingu-Mae became associated with a fashionable image and were featured in fashion magazines, which eventually attracted big investment companies.

Beginning in the 2000s, these investment companies began buying commercial properties in the close alleys of Jingu-Mae by forming the Real Estate Investment Trust (REIT), through which they made various spatial renovations to these buildings and then selected their desired tenants so as to raise the buildings' exchange value. Consequently, land prices in Jingu-Mae's close alleys are rising slowly.

We present a new hypothesis in which we predict that the new image of the JinguMae close alleys as a fashionable cultural center due to the presence of the clothing design industry will raise the exchange value of the clothes designed there. Support for this hypothesis would indicate that global cultural production of clothing provides opportunities for real estate investment. As a consequence, local residents, culturally designed clothing, and retail companies will become strongly connected to the global economy, which is already influenced by investment companies. This connection to the global economy could foster sustained urban growth of the fashionable quarters in Jingu-Mae.

\section{1. 研究の背景と本研究の目的}

1920 年代以降、都市社会学の研究者たちは、都市の成長が何を促すのかという問いにた いする答えを追求してきた。しかし1980年代になると、グローバル経済の進行により工 場が新興工業国に移転し、大都市の衰退を促した。こうした背景のもと、現代都市社会学 
においては、何が都市の成長を促すのかという問いにたいする答えを追求してきた。 たとえばサスキア・サッセンによるグローバル都市を挙げることができる [Sassen 2001 =2008]。サッセンによるグローバル都市の研究は、グローバル経済のコントロール機能 の観点から、都市成長の原動力を見出してきた。サッセンは、知識生産に基づく金融派生 商品（デリバティブ）の開発が、グローバル都市の原動力となると考えている [Sassen $2001=2008]$ 。とりわけサッセンは、投資がグローバル経済の進行を促すものと捉えてい る。

サッセンがデリバティブとして捉えてきた、不動産の証券化をつうじた投資と、都市の 成長を結びつけた研究は、おもに経済地理学において蓄積されている。クリス・オールズ は、上海中心部のような大規模不動産開発における資金調達の代表的手段として、不動産 の証券化をつうじた活発な投資をみいだした [Olds 1995]。レイチェル・ヴェーバーの研 究では、短期間でマージンを得ることができる、不動産投資信託が活発化していることに 言及し、現代大都市再開発における重要な手段であると論じた [Weber 2002]。そして ニール・スミスは、不動産の証券化という投資を強く意識した都市成長政策が、とりわけ 現代社会において重要であることを認めている [Smith 2002]。さらに、加茂利男の研究 も、不動産の証券化を、世界都市における新しい投資と開発の手段として位置づけている [加茂 2005]。

そして、矢部直人による東京都心における高級街区の不動産投資に関わる研究を挙げる ことができる [Yabe 2008; 矢部 2008]。矢部は、東京都港区南青山と渋谷区神宮前の高級 街区において、2000年代における不動産の証券化が活発化したことを明らかにした。そ のうえで、不動産投資信託が、東京都心の高級街区における空間変容を促す可能性につい て論じている（Yabe 2008; 矢部 2008]。

知識生産が都市の成長を促すという考えを持つ研究は、グローバル経済の観点からの研 究だけではない。都市の文化生産研究においても存在する。都市の文化生産研究とは、衣 料デザイン、グラフィックデザイン、アートや、音楽制作などの文化生産が、都市成長の 原動力となることを実証的に明らかにしてきた研究領域のことである $[$ Zukin 1988; Bovone 2005; Lloyd 2006; 三田 2013]。

都市の文化生産研究では、ピエール・ブルデューの『芸術の規則』における「文化生産 の場 (Champ)」における「純粋生産」と「大量生産」という理論枠組みに依拠しながら、 研究が進められてきた [Bourdieu $1992=1995]$ 。まず、東京都心における都市細街路が、 住宅街から、グローバルな衣料デザインの研究開発拠点へと変容した過程を明らかにした 研究が挙げられる [三田 2013]。この研究は、「グローバルな衣料文化生産の場」という 理論枠組みをもとに、グローバルな純粋生産とグローバルな大量生産をコントロールしな がら、衣料文化生産のグローバルな研究開発拠点として都市細街路が再成長してゆくと結 論づけた [三田 2013]。 
つぎに、シャロン・ズーキンとアルビン・コスタによる、ロウワー・マンハッタンの The East 9th Streetを事例とした研究がある [Zukin and Kosta 2004]。この研究では、大量 生産や流行を好まない、純粋生産志向の衣料やアートのデザイナー、ミュージシャンや、セ レクトショップのオーナーが the East 9th Streetで独自の下位文化を形成していることが 示されている。荒廃した街区に純粋生産を志向するミュージシャンやセレクトショップ経 営者と顧客が閉鎖的ネットワークを形成し、独特な街区の雾囲気が醸成されてきたことが 記述された。この街区を、ズーキンとコスタは、“Bourdieu Off-Broadway”と名付けた [Zukin and Kosta 2004]。

さらに、リチャード・ロイドによる、シカゴのウィッカーパークの研究を挙げることが できる。ウィッカーパークは、2000年代までは自由に活動するミュージシャンやペイン ティングを専門としたアーティストや、webデザイナーが、荒廃した街区の物件を安価な 家賃で借り、安定的な雇用を求めていた。ロイドはこうしたひとびとが集まる街区を、 「ネオ・ボヘミア」と称した [Lloyd 2006]。

このように、東京、ニューヨークや、シカゴなどの、先進国諸都市の都市研究者が、グ ラフィックデザイン、アートや、音楽制作などの文化生産が、都市成長の原動力となるこ とを実証的に明らかにしてきた。そのうえで、事例記述を都市社会学の文脈で考察し、学 術的意義を深めてきた。

しかし、これまでの都市社会学において、衣料文化生産をグローバル経済の進行を促す 投資と結びつけて論じたものは、まだ登場していないといえる。それではなぜ、衣料文化 生産と投資を結びつけた研究をおこなう必要があるのか。それは 2000 年代以降、ニュー ヨーク、ミラノ、キャンベラ（オーストラリア）や東京などの先進国諸都市における ファッショナブルな雾囲気の高級街区にたいし、機関投資家による投資を活発におこなつ ているという経験的事実があるからである。とりわけ2000年から不動産投資法人の設置 が許可されたアメリカとオーストラリアでは、高級衣料小売店舗や衣料デザイン事務所が 集積するビルに投資をおこない、資産運用をもとに大きなマージン（利ざや）を得ている。 日本でも 2005 年に東京証券取引所で、不動産投資（J-REIT）の取引所が開設され、日本国 内の企業でも不動産投資法人の設置が許可された。一部の不動産投資法人が衣料文化生産 街区への投資をつうじて、大きなマージンを得ているのだ。

それゆえ、グローバル経済をけん引する投資の観点から、衣料文化生産街区の投資主導 の成長過程を明らかにし、それを都市社会学の文脈で考察を深めることは、グローバル都 市における衣料文化生産と、グローバル経済を結びつけながら、都市細街路のさらなる成 長過程を明らかにできるという新しい都市社会学的研究としての意義があるといえる。

そこで本研究は、都市成長の原動力のひとつである衣料文化生産が、衰退傾向にあった 街区の成長を促すと、その後どのような都市成長を促すのかという問いを、グローバル経 済をけん引する、投資の観点から明らかにする。最後にそれを現代都市社会学の観点から 
考察を深めてゆくことを目的とする。

本論文の構成は、つぎのとおりである。まず 2 . では本研究の調査対象地と調査方法につ いて述べる。3.では、渋谷区神宮前の都市細街路の変容過程を土地資産バブル期から今日 まで概要的に記述し、不動産投資信託 REIT (リート) が渋谷区神宮前の都市細街路の再 成長をもたらした過程について記述する。4.では、不動産投資法人と都市細街路の低層ビ ルに住まう住民の利害が一致した理由について明らかにする。さいごに5.では、本研究の 結論を述べる。

\section{2. 調査対象地と本研究の調査方法}

\section{1 本研究の調査対象地}

本研究の調査対象地は、東京都渋谷区神宮前の都市細街路である。1990年代から「裏原 宿」「キャットストリート」として若年層に知られている都市細街路である。東京都渋谷 区は、東京23区の南西部に位置する。住民登録人口は、221,811人である (2018.4.1現 在。総務省「住民基本台帳に基づく人口」)。渋谷区神宮前は、渋谷区の北西部に位置す る。神宮前は 1 丁目から 6 丁目により構成されている。1960年に住居改正表示が行われ、 現在の神宮前という地名になつた。

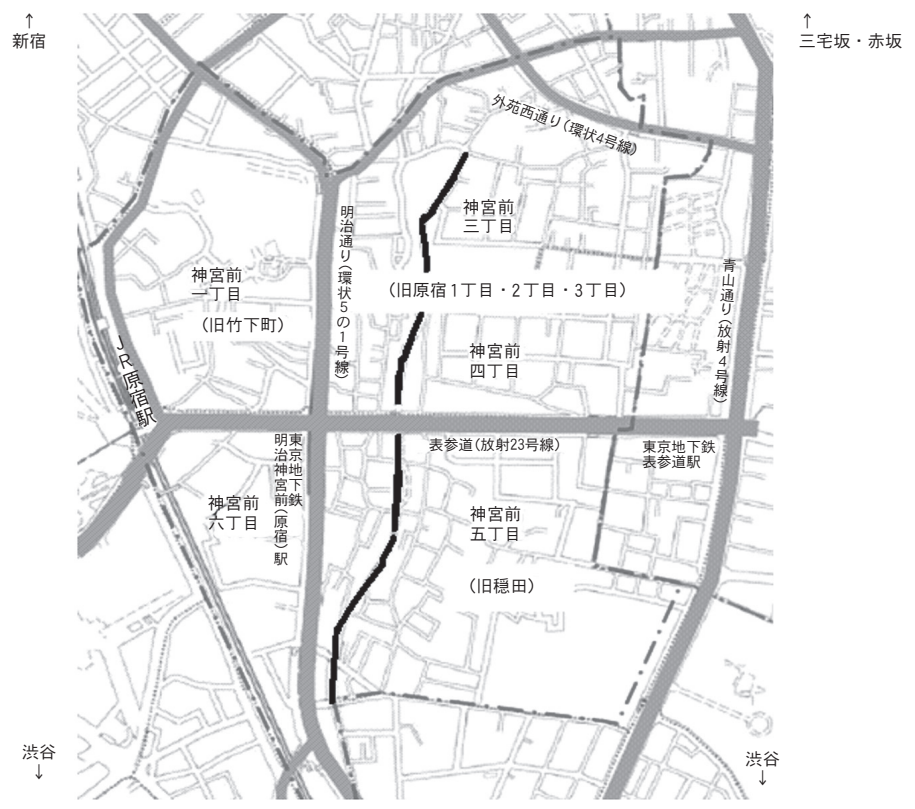

地図 1 神宮前をしめす地図。太線の部分が、通称「裏原宿」「キャットストリート」(補助道路164号線)。 出典：渋谷区役所まちづくり指針図 2012 年 12 月 26 日閲覧。 ※筆者が加筆。[三田 2013 の地図を再掲載］ 
神宮前 1 丁目は、旧竹下町である。現在の竹下通りがある地域に該当する。神宮前 2 丁 目、3丁目と 4 丁目は、旧原宿である。神宮前 5 丁目、6丁目は、旧隠田（穏田）である。 隠田は、神宮前の南側で、渋谷駅に近い。旧原宿と旧隠田に該当するエリアに現在、高級 衣料デザイン事務所や高級ブランド衣料小売店舗が集まっている。なお神宮前 3 丁目、4 丁目、 5 丁目は、港区南青山にも近接している。また神宮前 $6 丁$ 丁目は渋谷区渋谷、渋谷区 東という場所にも近接している。

2015 年 7 月 1 日時点の町丁目別人口は、神宮前 1 丁目が 2,005 人、神宮前 2 丁目が 2,095 人、神宮前 3 丁目が、 3,180 人、神宮前 4 丁目が 1,167 人、神宮前 5 丁目が 2,038 人、そし て神宮前 6 丁目が 1,080 人である (平成 27 年 7 月 1 日。総務省統計局『国勢調査』)。

渋谷区神宮前の都市細街路は、元来住宅街であった。1980年代後半の土地資産バブル 期に固定資産税と相続税の支払いに耐えかねた住民が土地を売却した。残つた住民は、用 途地域指定制度において許可される限りの低層ビルを建設した。上階に自宅を設け、下の 階に衣料デザイン事務所や高級衣料セレクトショップを入居させ、高い家賃設定で貸し出 すことを想定していた。

しかし 1990 年代の土地資産バブル崩壊を契機として、渋谷区神宮前の不動産価值が急 落した。低層ビルのオーナーである住民が少しでも利益を回収するために、ヤングアダル 卜層向けの高級衣料デザイン事務所と、輸入高級衣料路面店（セレクトショップ）を、安 価な家賃でテナントとして誘致した。それにより渋谷区神宮前の細街路が「ファッション の街」として若年層から注目を集めた。若年層向け雑誌メディアが、「裏原宿」「キャット ストリート」という愛称をつけ、若年層に呼ばれてきた街区として変容してきた。

そして 2005 年になると、日本政府により投資にかんする規制緩和がおこなわれた。小 売業の入居するビルへの投資を専門とした不動産投資法人 ${ }^{1)}$ が、渋谷区神宮前の都市細街 路にたいし、住宅街からファッショナブルな街区へと変容した過程に着目した。この不動 産投資法人が、渋谷区神宮前における都市細街路の土地建物を複数取得し、不動産の証券 化を行った。この不動産投資法人は、物件のブランド価值を高めながら資産運用をおこな い、大きなマージン (利ざや) を生み出すという事業を進めた。それゆえ、都市細街路の 変化を主導する主体となりつつある。

こうした経験的事実から、東京都渋谷区神宮前の都市細街路に焦点をあてることによ り、衣料文化生産街区が、グローバル経済をけん引する投資をつうじて、さらなる都市細 街路成長の過程を明らかにできると、筆者は考えた。以上の理由にもとづき、筆者は、渋 谷区神宮前の都市細街路を調査対象地として選定した。

\section{2 本研究の調査方法}

本研究の調査方法は、以下のとおりである。筆者は 2010 年代初頭から、表参道原宿地 区のなかで唯一の商店街として位置づけられてきた「隠田商店街」が存在していた神宮前 
6 丁目（旧隠田）の町会長と、隠田商店会長を務めた男性（現在は地元不動産業者）と、神 宮前 2 丁目、3丁目、 4 丁目、5丁目と 6 丁目に住む地元住民にたいし、聞き取りをおこ なってきた。

聞き取り実施の場所は、神宮前 6 丁目に所在する不動産屋兼婦人服店や、近所のコー ヒーショップである。2011年における調査内容は、穏田の過去の商店街から現在までの空 間変容過程における地元住民の役割であつた。なお神宮前 $6 丁$ 丁目に、旧原宿の住民や、旧 穏田の住民が定期的に会合をおこなう大きな集会所があつた。また旧・隠田に都市銀行退 職者が 2 名住み、土地にかんする長けた知識を保有していたこともあつた。それゆえ調査 対象者の内訳として、神宮前 6 丁目の住民が多くなつている。

2013 年から 2016 年にかけての調査では、神宮前（旧原宿・隠田）の都市細街路におい て、不動産投資法人とデベロッパーが、投資行動をおこなう方法について、大手不動産企 業社員や大手商社社員への聞き取りをおこなつた。また地元の資料調査をおこない、不動 産投資の文献をつうじて不動産投資信託にたいする理解を筆者は深めた。

さらに筆者は、渋谷区神宮前の細街路における、高級ブランド衣料品店や高級衣料デザ イン事務所の経営者やスタッフ（高級衣料貿易会社のプレス担当）などにたいして、2002 年から 2015 年まで調査をおこなってきた。2008年から 2018 年にかけての調査は断続的に 行われた。まず、衣料デザイン事務所と衣料小売企業向けのフィナンシャルプランナー (現在は福岡市在住。週 2 回東京へ向かう) への半構造化面接にもとづく聞き取りをおこ なった。そればかりでなく、衣料デザイン企業向けコンサルティング企業の代表取締役 （勤務地は六本木。平日は東京勤務）の人物にたいして、半構造化面接にもとづく聞き取 りを行った。それにより、衣料文化生産街区における不動産投資にかんする情報を得た。

聞き取り場所は、2008年から 2016 年 3 月にかけては、六本木西麻布交差点付近に所在 する、高級衣料ブランドのプレスリリーススタジオと、渋谷区神宮前の細街路にあるカ フェレストラン「ロータス」であつた。2016年 4 月から 2018 年 3 月にかけての聞き取り 場所は、筆者と彼／彼女らにとって利便性の高い、JR博多シティの飲食店、天神VIORO (商業施設) のコーヒーショップや、西鉄天神ソラリアステージのコーヒーショップで あった。聞き取り結果に関しては、REITに関する文献、フィナンシャルプランナーやコ ンサルタントからの説明と照合し、ズレが生じていないかどうかについて、確認をおこ なった。

\section{3. 渋谷区神宮前の都市細街路の変容過程}

\section{1 表参道の高級街区化}

東京都では 1980 年代以降、従来の製造業の衰退によって、ブルーカラー職が減少した。 情報サービス経済化が、外資系の金融・保険・不動産部門を集中させた。オフィスビルの 
みならず、高所得者層向けの商業施設も増加した。

とくに渋谷区神宮前に近接する、港区六本木、麻布エリアの外資系金融・保険 - 不動産 部門に勤めるひとびとや2)3) 4) 渋谷区神宮前、港区六本木、麻布、三田エリアに集まる 大使館 ${ }^{5)}$ に勤めるひとびとが、高所得者層として位置づけられる。

上述の外資系金融・保険・不動産部門や、大使館に勤める高所得者層が表参道に集ま り、高級衣料品への需要を常に高めてきた。それにより、『Gruppo Gucci』(グッチ)、

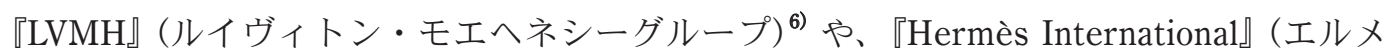
ス）などの大資本高級ブランド企業直営店（もしくはフランチャイズ店舗）が表参道に開 店した。

また現在LVMHグループ傘下のPRADA 社は、1987年に表参道に現在の路面店をオープ ンさせた。PRADAは、路面店をオープンさせるために、さくら銀行（現在の三井住友銀 行）から約 $4,000 \mathrm{~m}^{2}$ の土地を、約 50 億円で購入した (2017.5 信託銀行行員への聞き取り)。

また、実業家でもある有名歌手が経営していた企業が倒産し、その後土地の複雑な権利 関係を三井不動産が解消した。その土地を、LOUIS VUITTON（ルイ・ヴィトン）が 1997 年に購入した (2017.5信託銀行行員への聞き取り)。LOUIS VUITTONのばあい、現在の 表参道店を、東京におけるLOUIS VUITTONのフラッグショップ(旗艦店) として位置づ けている。またLOUIS VUITTONの東京支社にあたる、LOUIS VUITTON JAPAN (ルイ・ ヴィトン・ジャパン）を、表参道の自社ビルに設置した ${ }^{7)}$ 。こうした外資系高級ブランド 衣料の路面店や、外資系高級ブランド大資本の東京支社機能が集中することにより、表参 道は高級街区として発達してきたのである。

\section{2 渋谷区神宮前における都市細街路への経済的波及効果の期待}

高級街区・表参道の裏に位置する、渋谷区神宮前の細街路は、1964年東京オリンピック 開催時において、東京都心部を南北に結ぶ明治通りの補助道路第164号線として使用され る予定であった [三田 2013]。しかし、現在は遊歩道となり、補助道路として使用されて いない。渋谷区神宮前の遊歩道は、源流が新宿御苑の渋谷川を暗渠化し完成した。暗渠化 した理由は、遊歩道として整備するためではなかった。東京都心を南北に貫く明治通りの 補助 164 号線として機能させるために、渋谷川を暗渠化したのである [三田 2013]。

しかし、暗渠化し整備した明治通りの補助道路第 164 号線の道幅が、補助道路の要件を 満たす 8 メートルに満たなかったことが判明した。補助道路 164 号線沿いには、住宅や生 鮮食料品店を取り扱う地元商店が密集していた。そのため補助道路 164 号線に自動車を走 らせると、危険であるという問題が浮上した。こうした経緯のもと、明治通りの補助道路 164 号線は使用されなかった（2011.3.7 S氏）。この補助 164 号線は、現在の遊歩道として 整備された。沿道には衣料デザイン事務所や小売店舗が入居した低層ビルが並んでいる [三田 2013]。 
さらに渋谷区神宮前の細街路のほとんどが、現在の第一種低層住居専用地域、第二種低 層住居専用地域と、第一種中高層住居専用地域として指定されている。制度上の特例とし て、商業ビルのなかに住民が居住していれば、商業向け低層ビルに建て替えてもよい。土 地資産バブル期に、神宮前の都市細街路に残つた住民が、この特例を使いながら住居を低 層ビルに建てかえた。ビルオーナー（住民）は、テナントに高級衣料デザイン事務所や高 級衣料品小売店を高い家賃で入居させ、高所得者層を顧客として取り込むことを期待して いた。高級街区・表参道からの経済的波及効果が期待されていた。

\section{3 神宮前の都市細街路における土地資産バブル崩壊}

ところが、1990年代前半における土地資産バブルの崩壊により、土地資産価值が急激に 下落した。国土交通省の公示地価価格によれば、渋谷区神宮前 $4 丁$ 目 14 番地の公示地価価 格は調査が始まった 1993 年 7 月 1 日においては、 $1 \mathrm{~m}^{2}$ あたり、約 250 万円であった。その 後土地資産バブル崩壊の影響を受け、渋谷区神宮前における細街路の不動産価値は、2000 年まで低下した。2000年における当地点の公示地価価格は、 $1 \mathrm{~m}^{2}$ あたり、約 82 万 2000 円 であった。土地資産バブル期においてすでに低層の複合ビルを建設していた住民や業者 は、少しでも利益を回収したいという思惑があった。

それゆえ低層ビルのオーナーは、少しでも利益を得ることを目的とし、家賃の值下げを おこなった。その後、東京都心において安価な家賃の物件を求めていた高級衣料デザイ ナーやブティック経営者たちが、渋谷区神宮前の細街路の物件に拠点を構えることができ た。この過程を経て、1990年代前半以降に、暗渠化された渋谷川上の遊歩道一帯に、革新 的デザインの衣服をうみだす高級衣料デザイナーの事務所や、高級衣料を専門としたセレ クトショップが増加した。同時期に、雑誌メディアによる情報が、充実した都会的ライフ スタイルを志向するヤングアダルト層のあいだで共有された。じっさい渋谷区神宮前にお ける都市細街路に高所得層が来街し、輸入高級ブランド衣料を購入する機会が増えてきた。

\section{4 渋谷区神宮前における公示地価価格の再上昇}

じっさい 1990 年代半ばにはいると、世界的に有名になった若手の高級衣料デザイナー たちが、渋谷区神宮前における都市細街路に集まり、事務所を開設している。衣料デザイ ン事務所が増えはじめ、 5 年ほど経過した 2000 年以降、「裏原宿」「キャットストリート」 として有名になった神宮前の都市細街路の不動産価值が上昇した。表 1 とグラフ 1 は、神 宮前 4 丁目の公示地価価格を示したものである。なお、神宮前の都市細街路における不動 産価格を把握することはできなかった。そのため神宮前 $4 丁$ 目の公示地価価格を参考值と して示す。

表 1 とグラフ 1 から、1980年代の土地バブル資産期から 1990 年代にかけて、極端に公 示地価価格が下落していることがわかる。しかし 2003 年頃から緩やかに上昇し、2010年 
表 1 渋谷区神宮前における都市細街路（神宮前4-4-19）の公示地価価格（国土交通省）

\begin{tabular}{crcr}
\hline \multicolumn{1}{c}{ Date } & \multicolumn{1}{c}{ Price } & Date & \multicolumn{1}{c}{ Price } \\
\hline $1983 / 1 / 1$ & 940,000 & $2000 / 1 / 1$ & 822,000 \\
$1984 / 1 / 1$ & $1,120,000$ & $2001 / 1 / 1$ & 866,000 \\
$1985 / 1 / 1$ & $1,370,000$ & $2002 / 1 / 1$ & 860,000 \\
$1986 / 1 / 1$ & $1,772,000$ & $2003 / 1 / 1$ & 903,000 \\
$1987 / 1 / 1$ & $6,000,000$ & $2004 / 1 / 1$ & 955,000 \\
$1988 / 1 / 1$ & $9,620,000$ & $2005 / 1 / 1$ & $1,200,000$ \\
$1989 / 1 / 1$ & $13,475,000$ & $2006 / 1 / 1$ & $1,700,000$ \\
$1990 / 1 / 1$ & $9,910,000$ & $2007 / 1 / 1$ & $2,200,000$ \\
$1991 / 1 / 1$ & $11,500,000$ & $2008 / 1 / 1$ & $1,940,000$ \\
$1992 / 1 / 1$ & $9,000,000$ & $2009 / 1 / 1$ & $1,940,000$ \\
$1993 / 1 / 1$ & $5,500,000$ & $2010 / 1 / 1$ & $1,460,000$ \\
$1994 / 1 / 1$ & $1,600,000$ & $2011 / 1 / 1$ & $1,500,000$ \\
$1995 / 1 / 1$ & $1,210,000$ & $2012 / 1 / 1$ & $1,460,000$ \\
$1996 / 1 / 1$ & 968,000 & $2013 / 1 / 1$ & $1,460,000$ \\
$1997 / 1 / 1$ & 968,000 & $2014 / 1 / 1$ & $1,530,000$ \\
$1998 / 1 / 1$ & 880,000 & $2015 / 1 / 1$ & $1,580,000$ \\
$1999 / 1 / 1$ & 838,000 & & \\
\hline
\end{tabular}

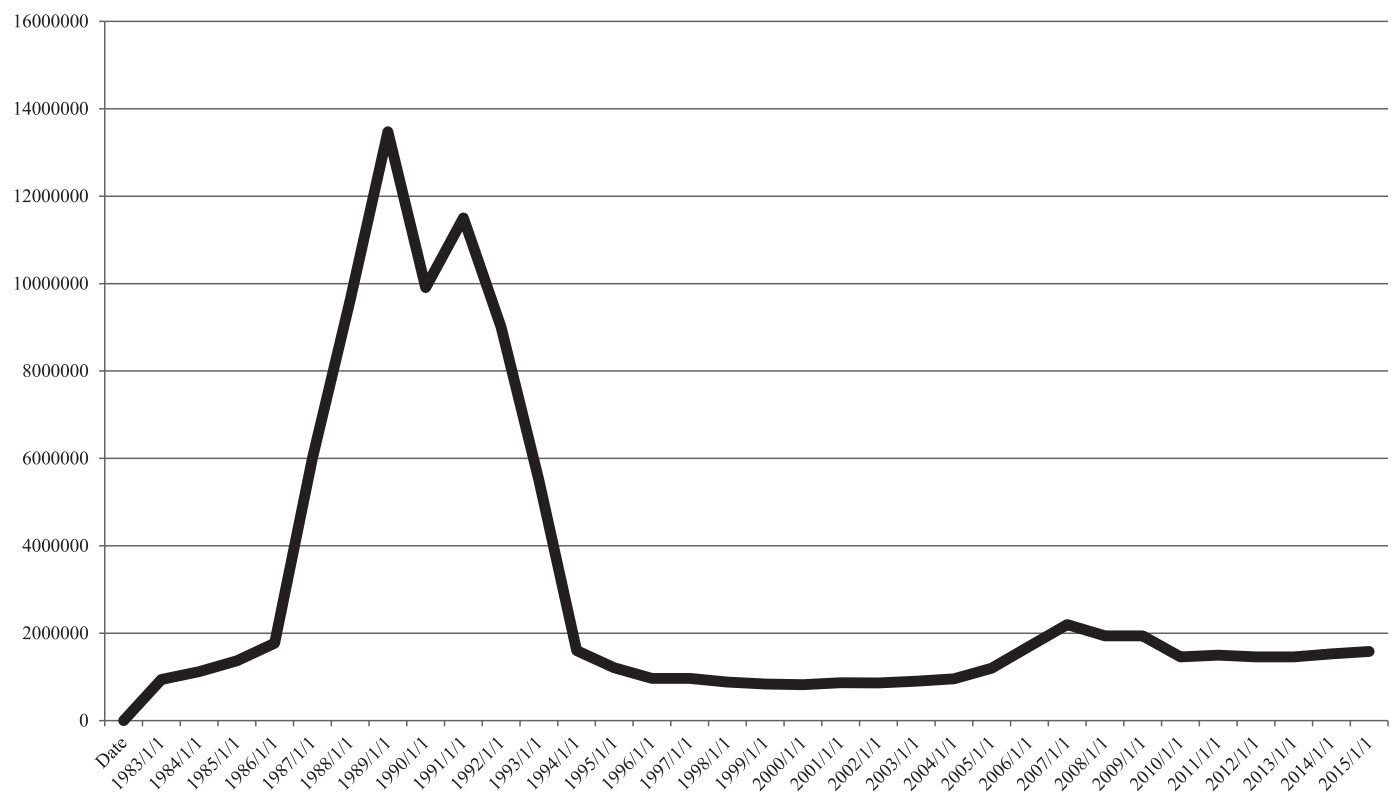

グラフ 1 渋谷区神宮前における都市細街路（神宮前4-4-19）の公示地価価格（国土交通省） 
代は、概ね 1990 年代よりも高い公示地価価格を維持している。

この理由は、世界的に高い評価がなされている高級衣料デザイン事務所や、国内で流通 していなかった衣料製品を販売開始したセレクトショップが増加したことによるものであ る。こうした話題が、渋谷区神宮前の都市細街路全体への経済的波及効果を高め、不動産 価值が上昇しはじめたものと思われる。

とくに不動産投資信託「J-REIT」が東証で開設された 2005 年以降は、これまで着眼さ れてこなかった、渋谷区神宮前の都市細街路への投資事業を開始した法人が登場した時期 でもある。

\section{5 神宮前の近未来を左右させる不動産投資「REIT」(リート)の仕組み}

先述のとおり、不動産投資信託「REIT」(リート)がアメリカ、オーストラリアやヨー ロッパに続き、日本でも許可されたという経緯がある。価值の上昇が期待される地区の土 地建物への投資が、この「REIT」(リート)をつうじて行われることとなる。

それでは、不動産投資信託「REIT」とは何か。不動産投資信託「REIT」（リート）とは、 不動産の証券化を意味するものである。不動産の証券化は、2000年にアメリカとオース トラリアで、REIT (Real Estate Investment Trust) として公式に認められた。ニューヨー ク証券取引所と、キャンベラ証券取引所でREITが取り扱われはじめた [三菱UFJ信託銀 行不動産コンサルティング部 2013]。

日本政府は、2001年より、外資系不動産投資法人に限って、日本国内の土地建物に対し て投資を行うことができるという規制緩和をおこなつた $[$ 三菱UFJ信託銀行不動産コンサ ルティング部 2013]。2001年以降、北米やオーストラリアの機関投資家が、東京都心に 活発な不動産投資を行いはじめた。日本政府は、こうした状況を考慮し、2005年に日本国 内の投資法人設置と取引を許可した。東京証券取引所において「J-REIT」（ジェイリート） という名称で、証券化された不動産の取引所を開設した [三菱UFJ信託銀行不動産コンサ ルティング部 2013]。なお REITには複数のタイプがあり、事務所投資型、商業施設投資 型、マンション投資型、ホテル投資型がある。渋谷区神宮前の都市細街路にたいする投資 は、事務所投資型と商業施設投資型のみである。

不動産投資は、つぎのプロセスを経て行われる。まずデベロッパー、不動産業者、メガ バンク、商社、証券会社や、鉄道事業者が、ペーパーカンパニーとしての不動産投資法人 を、たちあげる。とくに商業施設を専門とする不動産投資法人は、土地建物の価值を高め るために、テナント構成を収益性の高いものとし、マージンを得ることを目標とする (2017.10 コンサルタントへの聞き取り)。不動産投資法人が証券取引所に上場し、関連会 社間の売り買いをつうじ、マージンを得てゆくという戦略を採用しているものと思われる。

上述の手法を用いることにより、不動産投資法人を設置したデベロッパー、不動産業 者、メガバンク、商社、証券会社、商社や鉄道事業者は、大きなマージンを得てきた。た 
だし、不動産価值の著しい下落が発生するリスクが常につきまとう（2017.10 コンサルタ ントへの聞き取り)。

\section{6 明治通りに投資する不動産投資法人の登場——東急グループを中心とした投資事業}

それではなぜ、橴谷区神宮前に不動産投資法人が投資事業を行うのか。本節ではこの理 由を、事例記述をつうじて明らかにする。不動産の証券化「REIT」(リート) は、2005年 に東京証券取引所内に設置された。日本の企業も REITに新規参入ができるよう規制緩和 がおこなわれた。東証に設置された不動産投資信託の名称は、「J-REIT」（ジェイ・リート） である。

たとえば、森ビル傘下のデベロッパー、三菱商事や伊藤忠のような国内商社が、欧米の グローバル金融部門、保険部門や不動産部門と合同で企業をたちあげた。またゴールドマ ン・サックスのような外資系金融企業も、東京のメガバンクと業務提携を行いながら、不 動産投資への新規参入を行った。そして東急に代表される鉄道事業者は、東急のターミナ ル駅である渋谷駅や、明治通りの一部区間（渋谷駅から千駄ヶ谷まで）の沿道に、不動産 投資を集中しておこなった。

外資系企業にオフィスを貸し出す森ビルは、港区青山地区、六本木・麻布地区、赤坂・ 溜池山王に多数の自社ビルを多数所有している。近年の森ビルグループは、渋谷区神宮前 の表参道沿いの同潤会アパート跡地に、表参道ヒルズを2008年に開業させた。また森ビ ルは、神宮前交差点と至近距離にある、ラフォーレ原宿の底地を所有している。これらの 不動産を証券化し、資産運用をおこなっている。

東京都心を南北に貫く明治通りの渋谷駅から千駄ヶ谷までの区間の沿道には、東急グ ループの不動産投資法人が所有する商業施設を開業している。たとえば渋谷駅周辺のばあ い、現在建て直している東急東横店、若者女性に人気な「渋谷 109」（道玄坂）と、東急文 化会館跡地に渋谷駅の大規模再開発事業の一環として建設された「湶谷ヒカリエ」を開業 した。「渋谷ヒカリエ」のオフィステナントとして、横浜ベイスターズを保有するIT関連 企業「DeNA」(ディー・エヌ・エー) が入居している。現在六本木ヒルズにオフィスを構 えるGoogle 日本法人は、2018年秋に東急などが開発した「渋谷ストリーム」オフィス棟 に移転する。

また東急グループは、横浜から渋谷を結ぶ東急東横線（みなとみらい線・地下鉄副都心 線・東武東上線・西武線乗り入れ）と、神奈川県大和市の中央林間から、横浜市緑区、川 崎市の宮前区や、東京都世田谷区を経由して渋谷までを結ぶ、東急田園都市線（地下鉄半 蔵門線・東武伊勢崎線乗り入れ）のターミナル駅として、渋谷駅を位置づけてきた。東急 沿線に住まう住民の余暇に利用できる「渋谷 109」「渋谷Q-FRONT」や、小売店や「シア ターオーブ」により構成された商業施設フロア「ヒカリエ・シンクス」を開業してきた。 東急グループにおける再開発のなかで最も重要な投資事業として位置づけられている。 
さらに東急グループは、東急渋谷駅から地下鉄副都心線の明治神宮前（原宿）駅までを 回遊するひとびと（主に東急沿線住民）をターゲットとし、商業施設を明治通りの渋谷か ら千駄ヶ谷区間の沿道に相次いで開業している。その代表格が、「東急プラザ表参道原宿」 である。この商業施設は、表参道と明治通りが交わる、神宮前交差点に所在する。

なお東急プラザ表参道原宿が開業する前は、アメリカ発のカジュアル衣料を提供する

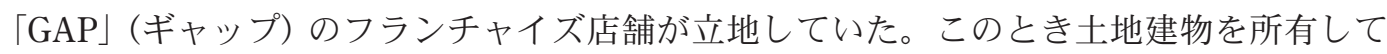
いた企業は、竹中工務店であった。竹中工務店は、土地資産バブル期以降に土地建物を東 武から購入し、GAPのフランチャイズ店舗が所在した。

現在では東急プラザ表参道原宿の直下に、東急東横線に乗り入れる、地下鉄副都心線の 明治神宮前（原宿）駅と、JR常磐線の土浦方面から小田急線の多摩センタ一方面に乗り入 れる、地下鉄千代田線の明治神宮前（原宿）駅がある。土曜日と祝日は全ての電車が停車 する。そのため、明治神宮前駅の利便性が高くなつている。

特に東急グループは、東急東横線と田園都市線の沿線に住居を構える住民をターゲット とした大規模商業施設を、渋谷駅だけでなく、その延長線上に位置づけられる、明治通り 沿いにも開業している。明治通りにおける東急グループによる大きな商業施設の開業も、 主に東急線沿線住民をターゲットとした、投資事業の一環として捉えることができる。

\section{4. 渋谷区神宮前の都市細街路に着目した不動産投資法人の登場一一住民との利害の一致}

\section{1 用途地区指定制度の例外に着目した不動産投資法人}

上述の東急グループの戦略とは、大きく異なる不動産投資事業を展開する、不動産投資 法人が登場した。それが、商業施設への投資を専門とする日本リテールファンド投資法人 である。日本リテールファンド投資法人は、ファッショナブルな䨌囲気が醸成されなが ら、衣料文化生産街区へと変容してきた渋谷区神宮前の都市細街路に着目した。これは森 ビルや、東急グループが見過ごしてきた場所であるといえよう。

日本リテールファンド投資法人は、ほかの不動産法人との差異化を図るために、渋谷区 神宮前における都市細街路の土地建物を複数取得し、資産運用を本格化した [三菱UFJ信 託銀行不動産コンサルティング部 2013]。日本リテールファンド投資法人が取得した物件 は、表参道と明治通り裏の都市細街路に所在する、高級衣料デザイナー事務所やセレクト ショップが入居している。この不動産投資法人は、物件のブランド価值や経済的価值を高 めるための投資事業を遂行してきた。その結果、この投資事業から大きなマージンを得る ことができたのである。

渋谷区神宮前の都市細街路は、衰退傾向にあった住宅街から衣料デザインのグローバ ルな研究開発拠点へとして有名になつた。この時期には高級輸入衣料販売店（セレクト ショップ）も増加した。しかも渋谷区神宮前は、2020年東京オリンピックのメーン会場で 
ある、新・国立競技場（東京都新宿区。2018年 4 月 1 日現在、工事中）が至近距離に所在 する。機関投資家にとつて投資をおこなう格好の対象となるものと考えられてきた。

ただし、渋谷区神宮前における都市細街路は、第一種低層住居専用地域、第二種低層住 居専用地域や、第一種中高層住居専用地域に指定されている。神宮前小学校への通学路を 安全に管理するために、第一種文教地区指定がなされている。さらに「渋谷区まちづくり ルール」により、宿泊施設の設置は禁止されている(ビジネス用も含む)。21時以降の衣 料品店の営業や、ヘアサロンの営業を控える必要がある [三田 2013]。それゆえ神宮前の 細街路における不動産投資物件は、事務所と商業施設を備えた低層ビルに限定されている。

渋谷区神宮前の都市細街路には、閑静でファッショナブルな雾囲気の街区であることに 魅力がある。低層ビルを拠点としている衣料デザイナーにとつても、作業に集中できると いうメリットがある。

このような長所を保有する、渋谷区神宮前の細街路における低層ビル経営に着眼し、用 途地区指定制度の特例を駆使した不動産投資法人の代表格として、日本リテールファンド 投資法人を位置づけることができる。日本リテールファンド投資法人は、三菱商事（東 京)、グローバル金融企業のUBS（チューリッヒ）により設置された MC-UBSグループ傘 下のカンパニーである ${ }^{8)}$ 。日本リテールファンド投資法人は、親会社の三菱商事・UBS、 MC-UBS、さらに関電不動産 (関西電力グループ)、三菱商事とUBSが出資し設置した不 動産投資法人 MC-UBS City（オフィステナント向け不動産投資法人）と、証券化された不 動産の売買を行い、大きなマージンを得てきたことがうかがい知れる。

現在の日本リテールファンド投資法人は、東京都、神奈川県、埼玉県、千葉県における 小売業が入居する土地建物に、投資を重点的に行ってきた。これまで、一都三県における 小売業の入居ビルに投資をおこない、得られたマージンを顧客に配当するという、独自の 戦略で、事業を展開してきた。2018年 3 月現在の投資対象物件は 100 件である (2018.3 同 社 HP)。またイオン ${ }^{9)}$ のような一部の大規模商業施設や、駅前の飲食店が入居するビルも 投資対象物件としている。

日本リテールファンド投資法人による投資は、低層ビルに焦点をあてた投資である。東 急による明治通り沿いの大規模商業施設にたいする投資事業や、外資系高級ブランド大資 本、メガバンクや、森ビルが土地建物を所有している表参道への投資とは異なる。

\section{2 不動産投資法人と住民のあいだの利害の一致}

渋谷区神宮前の都市細街路における用途地区指定制度には厳しい制限がある。ただし住 民が入居していれば、同じ低層ビルのなかに、衣料デザイン事務所や衣料品店を入居させ て良い。この特例を駆使するために、上述の不動産投資法人は、まず住民から土地建物を 購入（または借り入れ）し、不動産投資法人による投資物件とした。ただ、渋谷区神宮前 の都市細街路から住民を流出させると、テナントとして入居している事業所の営業が不可 
能になる。そこで、上述の不動産投資法人のばあい、住民をそのまま低層ビルに居住さ せ、所有者を住民から不動産投資法人に移行するという書面上の変更をおこなった。つま り住民が不動産投資法人に土地建物を売却（または貸し出し）する。逆に住民が不動産投 資法人から低層ビルを借りる。所有者の移行が、渋谷区神宮前の都市細街路における投資 を可能にしてきた。

神宮前の都市細街路に居住するひとびとは、高齢者が多い。低層ビルの所有者が不動産 投資法人となることにより、高齢者住民によるビル管理に関する労力を解消させたという (2017.12 住民への聞き取り)。より正確にいうと、不動産投資法人が発注した電力会社、 ガス会社、エレベー夕設置事業者や、建物の空間を更新する事業者が、ビルの更新工事を 定期的におこなっている。以前はこうした工事の手配については、住民が行っていた。し かし住民の高齢化に伴い、自力で更新作業の手配を行うことが難しくなったのである。と くに渋谷区神宮前には、細街路ばかりでなく、狭险道路も多い。火災や地震などの緊急時 対応について、高齢者住民は迅速的確に避難できるかどうか不安であるという（2011.3 地 元住民への聞き取り)。

それにより不動産投資法人が手配したビル管理会社、清掃会社、警備会社や、エレベー タのメーカーが、低層ビルのメンテナンスを定期的におこなうことができた（2018.1 商社 社員への聞き取り)。こうして、渋谷区神宮前の都市細街路に住まう住民と、上述の不動 産投資法人のあいだの利害が一致したのである。

\section{3 不動産投資法人による主な投資物件}

表 2 は、日本リテールファンド投資法人による投資物件をまとめたものである（橴谷区 神宮前と港区青山地区の夕筆者が抜粋)。この不動産投資法人が投資している物件のう ち、渋谷区神宮前に所在している投資物件の概要を記している。地図 2 では、この不動産 投資法人による投資物件のうち、渋谷区神宮前に所在している投資物件をマークで示して いる。

日本リテールファンド投資法人による投資物件は、東京都、神奈川県、千葉県と埼玉県 に 100 件ある。これは、投資物件 1 件ごとにテナント構成を安全なものとし、ビルメンテ ナンス、警備システムが充実した物件としている。そこに高級衣料デザイナーの事務所 や、国内初の高級衣料ブランドを扱う、セレクトショップが入居した。それにより、上述 の不動産投資法人は、低層ビルの経済的価值をも高めてゆくことを可能にした (2017.3 機 関投資家に勤務する男性への聞き取り)。

\section{4 不動産投資法人が評価する神宮前の都市細街路の役割}

高級街区である表参道の裏側に位置する都市細街路に集まる事業所は、衣料デザイン事 務所や、セレクトショップだけではない。雑誌のフォトスタジオ、ファッションショーに 
表 2 日本リテールファンド投資法人 渋谷区神宮前 (一部港区南青山) への投資物件

\begin{tabular}{|c|c|c|}
\hline G ビル南青山 02 & 東京都港区南青山 5 丁目 & カフェラウンジや小売店が入居する都市型商業店舗が入居。 \\
\hline Gビル代官山 01 & 渋谷区恵比寿西 1 丁目 & $\begin{array}{l}\text { 代官山駅と連接した建造物。東横線代官山駅改札前に、衣 } \\
\text { 料デザイナーたちが集まるカフェ「Sign」が入居。 }\end{array}$ \\
\hline Gyre ジャイル & 淽谷区神宮前 5 丁目 & $\begin{array}{l}\text { 路面店には「ジンネル」等の世界を代表するラグジュア } \\
\text { リーブランド、ニーヨーク以外への出店が世界初となる } \\
\text { 「MoMA デザインストア」、「ミシュランガイド で1つ星 } \\
\text { を獲得した料理店「うかい亭」などが入居。 }\end{array}$ \\
\hline Gビル北青山 01 & 港区北青山 3 丁目 & 地下 1 階から 2 階に美容院、ブライダルサロンが入居。 \\
\hline Gビル神宮前 02 & 渋谷区神宮前 4 丁目 & $\begin{array}{l}\text { セレクトショップ本店（本社）や外資ブランドの旗艦店・ } \\
\text { オフィスが入居。 }\end{array}$ \\
\hline Gビル表参道 01 & 渋谷区神宮前 $6 丁$ 丁目 & 株式会社キデイランドの旗艦店舗等が入居。 \\
\hline G ビル神宮前 03 & 渋谷区神宮前 $3 丁$ 目 & セレクトショップの本店や外資ブランド大資本が入居。 \\
\hline Gビル南青山 01 & 港区南青山 5 丁目 & $\begin{array}{l}\text { 先進性、先鋭性の高い国内ブランドやプレステージブラン } \\
\text { ド、クリエイターズブランドなどが中心。 }\end{array}$ \\
\hline ラ・ポルト青山 & 渋谷区神宮前 5 丁目 & $\begin{array}{l}\text { フレンチレストラン、高級創作和菓子販売ショップ、ヘア } \\
\text { サロンなど、話題性があり人気の高い店舗が入居。 }\end{array}$ \\
\hline Gビル神宮前 06 & 渋谷区神宮前 $6 丁$ 丁目 & カジュアル系からトレンド系の中小規模のショップが入居。 \\
\hline $\begin{array}{l}\text { アーバンテラス } \\
\text { 神宮前 }\end{array}$ & 渋谷区神宮前 5 丁目 & $\begin{array}{l}\text { ハウスウェディング業界最大手テイクアンドギヴ・ニーズ } \\
\text { が運営する表参道 TERRACEの旗艦店等が入居。 }\end{array}$ \\
\hline Gビル表参道 02 & 渋谷区神宮前 4 丁目 & 世界的高級ファッションブランド企業が入居。 \\
\hline
\end{tabular}

2018年 9 月 28 日参照。(一部筆者加筆)。http://www.jrf-reit.com/portfolio/tokyo.html

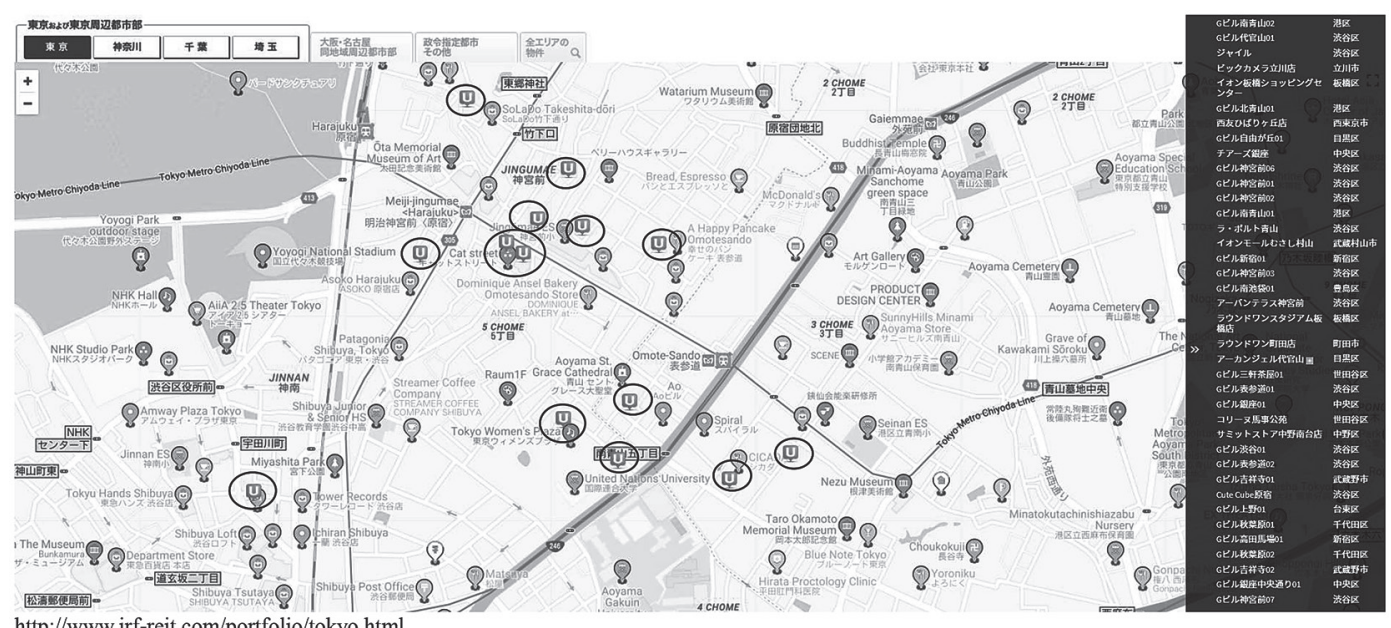

http://www.jrf-reit.com/portfolio/tokyo.html

地図 2 日本リテールファンド投資法人 渋谷区神宮前（一部港区南青山）への投資物件 2018 年 9 月 28 日参照。

丸印が、ジャパンリテールファンド法人の所有物件 (筆者加筆)。丸印が投資物件の所在地を示している。 
出演するモデルや、テレビ局に出演する著名人のスタイリスト事務所が低層ビルに入居し ている。さらに渋谷区神宮前の都市細街路には、国際的雑誌メディアのデザイン事務所も 所在している。またこうした事業所は、高級衣料ブランドを紹介するため、モデルの撮影 スタジオをも所有している。また、雑誌メディアは、最新の高級衣料デザインの動向を読 者に伝える必要がある。マンションの一室で行われる、法人向け品評会に参加できるよ う、神宮前の細街路における低層ビルに入居している (2014.5 雑誌編集者への聞き取り)。

本研究が焦点をあてている不動産投資法人は、渋谷区神宮前の都市細街路に集まる高級 衣料デザイン部門、小売部門や、衣料関連メディア部門を、グローバルな流行を生み出す 主体として評価している（2015.9 地元不動産業者への聞き取り）。だからこの不動産投資 法人は、渋谷区神宮前の都市細街路に着眼し、低層ビルを投資物件として取得してきたと いえる。しかもオーナーであった住民を借り手にするなど、知識を駆使した土地資産運用 をおこなつてきたということができる。

\section{5. 考察と結論}

このように本研究は、都市成長の原動力のひとつである衣料文化生産が、衰退傾向の街 区の成長を促すと、その後どのような都市成長を促すのかという問いを、グローバル経済 をけん引する、投資の観点から明らかにしてきた。本節では事例記述にもとづき、現代都 市社会学の文脈で考察を深めてゆくことを目的とする。

渋谷区神宮前の都市細街路では、1980年代後半から1990年代初頭にかけての土地資産 バブルの盛衰により、住宅街から、衣料デザイナーやセレクトショップが入居する低層ビ ルが立ち並ぶ街区へと変容した。とくに高級衣料デザイナーたちは、グローバルな純粋生 産とグローバルな大量生産を調整しながら、低層ビルのテナントとして入居し続けること を可能にした [三田 2013]。こうして渋谷区神宮前の都市細街路は、住宅街から高級衣料 デザインのグローバルな研究開発拠点へと変容した。

その後、2005年に日本政府が不動産投資信託にかんする規制緩和を行つた。三菱商事と UBSにより、不動産投資法人が設立された。この不動産投資法人が、衣料デザイン事務 所とセレクトショップが集まる渋谷区神宮前の都市細街路に着眼し、街区への投資事業を おこなつてきた。つまり本研究の事例記述から、衣料文化生産が都市細街路の文化的成長 を促すと、グローバル経済をけん引する、不動産投資法人による投資事業を誘発する。そ れにより、都市細街路の経済的成長が促されることがわかる。

このように考えてゆくと、衣料文化生産とグローバル経済をけん引する投資が、渋谷区 神宮前における都市細街路を、持続的に成長させてきたものと考えることができる。しか も衣料デザイナー、大手セレクトショップ企業や、高級衣料貿易業を営む個人事業主ばか りでなく、地域住民もグローバル経済に取り込まれながら、都市細街路の持続的成長が進 
行したのである。

都市社会学者は長いあいだ、都市の成長が何を生み出すのかという問いにたいする答え を追求してきた。それはシカゴ学派都市社会学の登場以降、長きにわたり、この問いにた いする答えが追求されてきた。ただ1980年代以降、グローバル経済の進行により、工場 が新興工業国へ移転し、大都市の衰退を促した。こうした背景のもと、現代の都市社会学 においては、何が都市成長を促すのかという問いにたいする答えを追求してきた。

しかしこれまでの都市社会学において、衣料文化生産をグローバル経済の進行を促す投 資と結びつけて論じたものは、まだ登場していなかった。そこで本研究は、衣料文化生産 と、投資がけん引するグローバル経済を結びつけながら、都市細街路の持続的成長を見い だしてきた。そこに本研究の現代都市社会学研究としての学術的意義がある。

さいごに本研究の課題について述べる。本研究では、ジェントリフィケーション研究と 関連づけながら考察が深められていない。本研究の調査対象地である渋谷区神宮前におけ る都市細街路の変容は、低所得者層の排除を伴うジェントリフィケーションとは大きく異 なるものである。その要因は、住民が土地建物を所有しているところにある。不動産投資 法人と都心住民の経済的取引に焦点をあてることにより、グローバル都市・東京ならでは の街区再開発過程を明らかにできる。本研究には、ジェントリフィケーションと不動産投 資の先行研究をレビューし、事例記述をもとにした都市社会学的考察を深めることが求め られている。

\section{註}

1）不動産投資法人は、ペーパーカンパニーである。そのため、実際の経営者は、商社、証券会 社や信託銀行、そしてメガバンクとなる。世界の大企業や大学なども資産運用の一環として REITを用いている。

2）外資系金融機関は、港区赤坂、南青山、麻布、西麻布、南麻布、元麻布、三田、芝大門、六 本木や、渋谷区神宮前 5 丁目に 18 件所在している (2018.3 筆者調査)。

3）港区六本木と西麻布に所在する外資系金融機関の代表例として、ゴールドマン・サックス証 券 (ニューヨーク) や、バークレイズ証券（ロンドン）を挙げることができる。法人顧客向けの 保険取扱会社は、アレン・アンド・オーヴェリー外国法共同事業法律事務所（ロンドン）とモ ルガン・ルイス\&バッキアス外国法事務弁護士事務所（東京）が代表的である（2018.3 筆者調 査)。

4）外資系不動産部門の代表例は、ゴールドマンサックス・アセットマネジメント（ニューヨー ク)、ゴールドマンサックスリアルティ・ジャパン有限会社 (ニューヨーク)、や、ウェストモ ントジャパンインベストメンツ (シカゴ) をはじめ、10件が確認されている (2018.3 筆者調 査)。

5）大使館のばあい、港区赤坂にはアメリカ大使館がある。オーストリア大使館は港区元麻布に ある。フランス大使館も南麻布にある。神宮前 $2 丁$ 目には、エストニア大使館とトルコ大使館 がある。ドイツ大使館は南麻布に立地している。

6） LVMHは 2000 年代以降、世界の名だたるブランド企業を買収し、高級衣料産業におけるコ 
ングロマリットを形成しはじめている。LVMHは投資の一環として、世界の高級ブランド企業 を買収しているものと考えることができる。

7）店舗は、住友商事により運営されているフランチャイズ店舗である。

8）三大都市圈のメインオフィスビルに投資をおこなうMC-UBS Mid Cityを、MC-UBSリアル ティと関電不動産開発（関西電力グループ）が設置した。

9）イオンは、自社の土地資産運用のために、イオンリート投資法人を設置している。

\section{文献}

Bourdieu, P., 1992, Les regles de l'art: genese et structure du champ litteraire, Paris: Editions du Seuil. (=1995石井洋二郎訳『芸術の規則 $1 \cdot 2$ 藤原書店.)

Bovone, L., 2005, "Fashionable Quarters in the Postindustrial City: The Ticinese of Milan." City and Community, 4-4:359-380.

加茂利男, 2005, 『世界都市一一都市再生」の時代の中で』有斐閣.

Lloyd, R., 2006, Neo-Bohemia: Art and Commerce in the Postindustrial City, New York: Routledge.

Olds, K., 1995, "Globalization and the Production of New Urban Spaces: Pacific Rim Megaprojects in the Late 20th century,” Environment and Planning A, 27: 1713-1743.

三田知実, 2013,「衣料デザインのグローバルな研究開発拠点としての都市細街路一東京都渋谷 区神宮前における住宅街からの変容過程一」『日本都市社会学会年報』31，61-76, 日本都 市社会学会.

三菱UFJ信託銀行不動産コンサルティング部，2013，『図解 不動産証券化とJ-REITがわかる本』 東洋経済新報社.

Sassen, S., 2001, The Global City: New York, London, Tokyo (New Updated Edition). Princeton, N.J: Princeton University Press, (=2008, 伊豫谷登士翁・大井由紀・高橋華生子訳『グローバ ル・シティ』筑摩書房.)

Smith, N., 2002, "New Globalism, New Urbanism: Gentrification as Global Urban Strategy," AntiPode, 34: 427-450.

和田清美, 1988, 「大都市都心周辺住宅地域の地域変貌——原宿」の地域社会研究—」『日本 社会事業大学社会事業研究所年報』24:287-310.

Weber, R., 2002, "Extracting Value from the City : Neoliberalism and Urban Redevelopment," AntiPode, 34: 519-540.

Yabe, N., 2008, "Impacts of Real Estate Securitization of Land Price Changes in the Inner City of Tokyo since 2001,” A Geographically Weighted Regression Analysis," Geographical Review of Japan, 81: 384-403.

矢部直人, 2008 , 「不動産証券投資をめぐるグローバルマネーフローと東京における不動産開発」 『経済地理学年報』経済地理学会 54 (4) : 292-309.

Zukin, S., 1988, Loft Living: Culture and Capital in Urban Change, New Jersey: Rutgers University Press.

Zukin, S., and E. Kosta., 2004, "Bourdieu Off-Broadway: Managing Distinction on a Shopping Block in the East Village," City and Community, 3-2: 101-114. et al. 2009, "New Retail Capital and Neighborhood Change: Boutiques and Gentrification in New York City," City and Community 8(1): 47-65. 
※本論文は、JSPS科学研究費・若手研究 (B) 研究課題番号：16K17242『衣料産業におけるグ ローバルな都市間分業——持続的都市成長の原動力——（研究代表者：三田知実）（研究開始 年月日 2016.04.01）における、研究成果の一部である。

(みた ともみ/熊本県立大学総合管理学部・准教授) （原稿受付 2017 年 11 月 30 日、掲載決定 2018 年 5 月 4 日） 